\title{
Recession, Local Fertility, and Urban Sustainability: Results of a Quasi-Experiment in Greece, 1991-2018
}

\author{
Rares Halbac-Cotoara-Zamfir ${ }^{1}{ }^{(D}$, Gianluca Egidi ${ }^{2}$, Rosanna Salvia ${ }^{3} \mathbb{D}$, Luca Salvati ${ }^{4}$, Adele Sateriano ${ }^{5, *}$ and \\ Antonio Gimenez-Morera ${ }^{6}$
}

1 Department of Overland Communication Ways, Foundation and Cadastral Survey, Politehnica University of Timisoara, 300224 Timisoara, Romania; raresh_81@yahoo.com

2 Department of Agricultural and Forestry Sciences (DAFNE), Tuscia University, Via San Camillo de Lellis, I-01100 Viterbo, Italy; egidi.gianluca@unitus.it

3 Mathematics, Computer Science and Economics Department, University of Basilicata, Viale dell'Ateneo Lucano, I-85100 Potenza, Italy; rosanna.salvia@unibas.it

4 Department of Economics and Law, University of Macerata, Via Armaroli 43, I-62100 Macerata, Italy; luca.salvati@unimc.it

5 Independent Researcher, PhD at Pontificia Universitas Lateranensis, I-00136 Rome, Italy

6 Departamento de Economia y Ciencias Sociales, Universitat Politècnica de València, Cami de Vera S/N, ES-46022 València, Spain; angimo1@doctor.upv.es

* Correspondence: adele.sateriano.pul@gmail.com

check for updates

Citation: Halbac-Cotoara-Zamfir, R.; Egidi, G.; Salvia, R.; Salvati, L.; Sateriano, A.; Gimenez-Morera, A. Recession, Local Fertility, and Urban Sustainability: Results of a Quasi-Experiment in Greece, 1991-2018. Sustainability 2021, 13, 1052. https://doi.org/10.3390/ su13031052

\section{Academic Editor:}

Wadim Strielkowski

Received: 22 October 2020

Accepted: 16 January 2021

Published: 20 January 2021

Publisher's Note: MDPI stays neutral with regard to jurisdictional claims in published maps and institutional affiliations.

Copyright: (c) 2021 by the authors. Licensee MDPI, Basel, Switzerland. This article is an open access article distributed under the terms and conditions of the Creative Commons Attribution (CC BY) license (https:// creativecommons.org/licenses/by/ $4.0 /)$.
Abstract: Fertility is a spatially non-stationary property of regional demographic systems. Despite the wealth of quantitative (micro-macro) information delineating short-term population dynamics in advanced economies, the contribution of economic downturns to local fertility has still been under-investigated along urban-rural gradients, especially in low-fertility contexts. Recent studies have assumed suburban fertility rates as systematically higher than urban and rural fertility rates. This assumption (hereafter known as the "suburban fertility hypothesis") has been grounded on stylized facts and spatial regularities in advanced economies that reflect a significant role of both macro (contextual) and micro (behavioral) factors that positively influence fertility in suburban locations. To test the suburban fertility hypothesis at the macro-scale, the present study compares gross fertility rates from seven regional units of the Athens metropolitan area between 1991 and 2018. A refined spatial analysis of gross fertility rates during an economic expansion (1999-2008) and recession (2009-2018) was carried out in 115 urban, suburban, and rural municipalities of the same area. Experiencing sequential waves of economic expansion and recession, Athens' sociodemographic dynamics were considered a sort of "quasi-experiment" for Southern Europe, linking late suburbanization with the multiple impacts of (rapid) economic downturns. Compared with both urban and rural locations, a higher fertility rate in suburban municipalities (15-20 km away from downtown Athens) was observed during the study period. However, a subtle distinction was observed during the economic expansion versus the recession. In the first period, the highest birth rates were recorded in industrial locations west of Athens, hosting economically disadvantaged communities with a relatively young population structure. With the recession, the highest fertility was associated with residential and service-specialized (wealthier) locations east of Athens, attracting resident population from neighboring areas, and better responding to crisis. The results of our study document how recent urban expansion and economic downturns have intrinsically shaped fertility dynamics, with implications for urban sustainability and social cohesion of metropolitan regions.

Keywords: economic downturns; demographic dynamics; suburban fertility hypothesis; Southern Europe

\section{Introduction}

In both affluent societies and emerging economies, demographic trends have diverged significantly across regions, following the increasing impact of economic downturns on 
population structures and dynamics [1-4]. At the same time, demographic dynamics have still been strongly associated with (more or less intense) urban-rural disparities, determining, for example, asymmetries in local job markets and a more polarized spatial distribution of businesses [5-8]. In these regards, socioeconomic processes that shape regional fertility were more intensively investigated, adopting quantitative approaches, statistical indicators, spatial analysis, and refined investigation techniques [9-12]. Together with gentrification and social segregation, economic factors (e.g., the intrinsic variability in housing and land prices) were at the base of regional fertility divides [13-16]. These forces have been explored at different spatial levels, evidencing the importance of (i) socioeconomic processes that influence urban-rural structures and (ii) population dynamics that leverage heterogeneous effects on fertility rates from defined territorial backgrounds, e.g., crystallizing distinctive demographic behaviors for urban, suburban, and rural locations [17-20].

In European countries, labor market transformations and spatially heterogeneous conditions for economic growth have been demonstrated to be (more or less tightly) associated with fertility in the last two decades [21-24]. Controlling for variation in economic conditions across regions and countries, fertility decline has been related mostly to an increase in unemployment [25-28]. The strongest fertility declines have been observed in areas where economic conditions deteriorated more rapidly with crisis [29-31]. As a fundamental target of any strategy of regional development, reducing social inequalities is supposed to have an intrinsic effect on fertility divides [32-34]. With socioeconomic disparities being a typical property of regional systems [35-37], fertility divides in Europe have been more intense between dynamic and marginal districts, with population aging, poverty, infrastructural gaps, and poor accessibility seen as indirect drivers of low fertility [38-41]. In such contexts, the importance of external disturbances affecting fertility has been only occasionally investigated [42], although fertility rates can be regarded as an indirect signal of resilience to short- and medium-term economic shocks.

In metropolitan regions, a number of studies investigating economic dynamics have been carried out, considering population trends at the base of long-term or medium-term urban evolution, but the specific demographic processes characteristic of such dynamics have been less extensively analyzed [2,3,8,12-17]. Although the spatio-temporal dimension of demographic dynamics, including - but not limited to-changes in fertility levels in urban areas, has been deeply evaluated in some specific contexts; a stronger integration of different disciplinary perspectives (the broader vision typical of urban geography, applied economics, and regional science and the specific perspective of spatial demography) was hypothesized to shed further light on the inherent complexity of long-term urban transformations [21,29,41], allowing a more accurate interpretation of socioeconomic changes at the base of metropolitan evolution [42]. Considering the socioeconomic diversification of local contexts as a relevant background [43-46], earlier studies have also stimulated a refined investigation of the intrinsic linkage between economic downturns, urban cycles, and fertility dynamics, with the aim of identifying demographically balanced regions that have been assumed to be more resilient to external shocks [47-50]. Economic downturns have variably affected the fertility response at the local community scale, depending on social structures, population dynamics, and the intrinsic characteristics of the production base [51-54]. In the context of job uncertainty, instability, or unemployment, high variability in land and housing markets- together with mortgage foreclosures-was demonstrated to have a direct influence on regional fertility rates [55-59]. Fertility declines have been associated with a (more or less intense) decrease in marriage rates, displaying a (direct or indirect) influence on birth rates [60-64]. Marriage and childbearing postponement, cohabitation, new family relations, and smaller households have also determined a more heterogeneous spatial distribution of local birth rates, especially in urban areas and peri-urban districts [65-71].

Based on these premises, the metropolitan scale is an appropriate analysis level when investigating fertility trends vis à vis economic downturns in Europe, a continent where fertility regimes have continuously adapted to intense socioeconomic transformations for centuries [72-75]. In this regard, it was demonstrated how fertility changes 
paralleled-or followed with a limited temporal delay-socioeconomic processes that have influenced residential structures, social inequalities, and spatial polarization of businesses over metropolitan regions [76-79]. The analysis of economic downturns contributes to re-frame regional (and local) fertility processes [80-85]. A refined comprehension of fertility dynamics and the underlying socioeconomic processes may inform (i) strategies that improve the sustainable management of urban regions, (ii) specific measures that enhance socio-spatial cohesion, and (iii) local developmental policies [86-91].

Literature evidence demonstrated a higher level of birth rates in suburban locations compared with both urban and rural areas of the same metropolitan region [92]. While city centers have been generally regarded as not "children-friendly" because of smaller dwellings, few green spaces, fewer services for childbearing, and poor amenities, it was assumed that fertility is highest in the countryside [69]. This assumption was documented in earlier studies [70]; however, more recent investigations have illustrated how suburban fertility has been becoming significantly higher than urban and rural fertility in recent times [93]. This process has primarily been associated with the inherent socioeconomic transformation of suburbs-being likely the most "children-friendly" locations along the urban-rural gradient-mixing the unique advantage of proximity to urban areas, the intrinsic benefits of natural amenities, and larger spaces in detached houses-the dominant residence in most advanced countries [92]. These stylized facts have been reported for various regions in Europe as a result of suburbanization impulses, and the related socioeconomic context has been assumed to exert a key impact that supports (or depresses) birth rates [93]. A persistently high suburban fertility rate influences population dynamics and social cohesion, contributing to urban resilience to external shocks and metropolitan sustainability at large [94-97]. However, the so-called "suburban fertility hypothesis" requires empirical confirmation in specific European contexts, and particularly, in Southern countries (where research in regional demography has been relatively less developed in comparison with Western, Central, and Northern Europe). Empirical verification of this hypothesis may specifically benefit from a refined investigation of the additional role of economic dynamics in a particularly turbulent period of Mediterranean history.

With this thinking in mind, the present study illustrates a diachronic analysis of fertility dynamics over sequential economic downturns in the last few decades, with the aim of demonstrating the validity of a suburban fertility hypothesis in Mediterranean cities. More specifically, an exploratory analysis of a gross birth rate was carried out at district (prefecture) and local (municipality) scale in Athens (Greece), comparing the last economic expansion (2000s) and recession (2010s). Given the financial crisis that has affected the Greek economy in the last decade, Athens provided a paradigmatic example of the possible response of local fertility to economic downturns at the residence, city, and metropolitan levels [98-101]. By outlining the intrinsic linkage between fertility dynamics and metropolitan sustainability, the implications of our study were finally discussed in a broader perspective of sustainable development, evidencing opportunities and limits of a comparative analysis of local fertility in urban, suburban, and rural contexts.

\section{Methodology}

\subsection{Study Area}

The selected area covers a large part of the territory administered by the Attica regional authority (Central Greece), corresponding with the NUTS-2 level of the European Nomenclature of Territorial Units (NUTS) adopted by Eurostat for statistical purposes. The area is characterized by a mixed topography, with mountain chains bordering the compact urban residences of the Greater Athens area and the dispersed residences in the Thriasio (Western Attica) and Messoghia (Eastern Attica) plains [102-104]. The study area also corresponded with the boundaries of the Athens Metropolitan Region (AMR), delineated following the functional criteria designed by the European Urban Atlas (Global Monitoring and Environmental Surveillance (GMES) Copernicus Land initiative) and used to identify metropolitan areas with more than 100,000 resident inhabitants in Europe [105-107]. The 
AMR was administered by an intermediate governance level (seven "regional units", corresponding with the NUTS-3 level of the European Nomenclature of Territorial Units) and a local level of governance (115 "municipalities", corresponding with the NUTS-5 level of the European Nomenclature of Territorial Units) [108]. "Regional units" and "municipalities" were thus regarded as the analysis domains in our study (Figure 1). With a surface area of nearly $3000 \mathrm{~km}^{2}$, including the island of Salamina close to the Piraeus harbor [109], the population concentration in the AMR increased from 400 inhabitants $/ \mathrm{km}^{2}$ (1951) to 1000 inhabitants $/ \mathrm{km}^{2}$ (2011), with an even larger spatial gap in population density between the AMR and the rest of Greece [105]. Functionally gravitating on downtown Athens $\left(40 \mathrm{~km}^{2}\right)$, the Greater Athens area is placed at the center of Attica and includes the central municipality of Athens, extending $430 \mathrm{~km}^{2}$ and displaying a high concentration of resident population (7000 inhabitants $/ \mathrm{km}^{2}$ in 2011). The remaining part of the region included both suburban municipalities (density $>1000$ inhabitants $/ \mathrm{km}^{2}$ ) and rural municipalities (density $<250$ inhabitants $/ \mathrm{km}^{2}$ ).
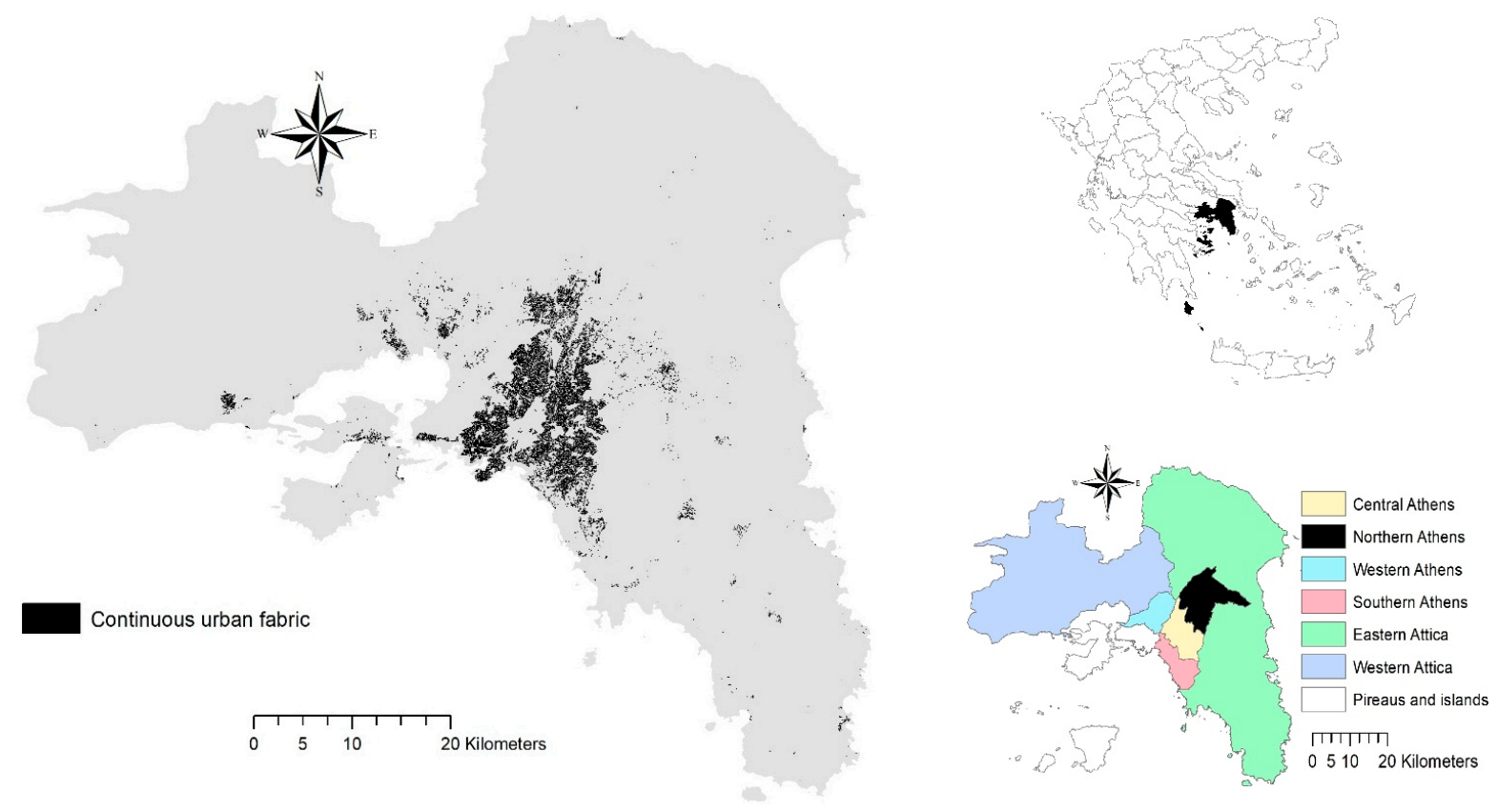

Figure 1. A map of the study area (Athens metropolitan region) with the spatial distribution of continuous urban fabric therein (left); the location of the Attica region in Greece (upper right) and the regional units partitioning Attica (lower right), both derived from elaboration on Urban Atlas maps and National Statistical Authority of Greece (ELSTAT) shapefiles.

\subsection{Data and Indicators}

The use of fertility time series in regional demography brings some methodological issues [110]. While the selected analysis' spatial scale correctly represents the urban gradient in the area, use of gross birth rates may result in a partial overview of local fertility, since demographic rates for smaller areas can be more sensitive to external factors, for example, in- and out-migration, than rates referring to larger districts [111]. To identify the most appropriate framework evaluating the intrinsic linkage between fertility and economic downturns, we assumed that "the importance of each variable depends on its spatial distribution" [110]. Considering the birth rate observed in neighboring municipalities as a predictor of fertility levels, our study proposed a descriptive analysis of local fertility that assumes how past fertility may be a factor of present fertility decline [8]. Indicators derived from this analysis were considered more reliable and stable from the statistical point of view, since fertility rates at the municipal level were calculated on a decadal base, reducing, in this way, the impact of inter-annual temporal variability and assuring the robustness of spatial estimates [112]. More specifically, a comprehensive analysis of a gross birth rate was carried out over a relatively long interval in the study area (1991-2018 at the "regional unit" 
level; 1999-2018 at the "municipal" level). This indicator was calculated as a generalized fertility rate based on the number of children to the total number of women in fertile age (15-49 years) and is largely used in regional demography $[3,72,110]$, controlling for the underlying socioeconomic background [113-115]. In details, period fertility rates were calculated from ELSTAT data as the ratio of the cumulated number of births at a given time point (i.e., 28 individual years from 1991 to 2018 for the "regional unit" level, and two decades, 1999-2008 and 2009-2018, for the "municipal" scale) to the average number of women at fertile age (15-49 years old) at the same place (i.e., region unit or municipality).

The local context ("municipal" scale) was delineated considering 70 indicators derived from national statistical sources, and classified into five analysis dimensions: (i) territory/topography/accessibility $(n=11)$, (ii) resident characteristics $(n=11)$, (iii) landuse $(n=21)$, (iv) economic base, income, and wealth $(n=15)$, and (v) socio-demographic aspects $(n=12)$. Indicators were selected according to earlier studies [101-103].

\subsection{Data Analysis}

The average fertility rates were calculated at both the regional unit and municipal levels, based on the selected time windows. The maps were realized, based on decadal fertility rates by time interval and municipality, with the final objective of identifying spatial similarities in fertility dynamics at the local community scale [104]. Using municipal data, a global Moran's index of spatial autocorrelation was computed on decadal fertility rates, as follows:

$$
I=\frac{N}{W} \frac{\sum_{i} \sum_{j} w_{i j}\left(x_{i}-\bar{x}\right)\left(x_{j}-\bar{x}\right)}{\sum_{i}\left(x_{i}-\bar{x}\right)^{2}}
$$

where $N$ is the number of spatial units indexed by $i$ and $j ; x$ is the variable of interest; $x$ is the mean of $x ; w_{i j}$ is a matrix of spatial weights with zeroes on the diagonal and $W$ is the sum of all $w_{i j}$. This approach estimates a correlation in a given variable among nearby locations in space. We used a weight matrix based on spatial distances that compute the $z$-scores of $I$ at four bandwidths $(5,10,20$, and $40 \mathrm{~km})$ and test for spatial dependence at $p<0.001$.

Variations over time in Moran's $z$-scores at different bandwidths were regarded as reliable estimates of intensity (and extent) of spatial interactions between municipalities, delineating a process of clustering in local fertility rates (when $z$-scores were determined as significant for spatial dependence) or spatial heterogeneity, when $z$-scores were determined as non-significant [116]. A diachronic analysis of high (or low) fertility clusters was run, considering the local Moran's coefficients of spatial autocorrelation (z-scores) by decade for each municipality of the study area. The municipalities were classified as (i) fertility hotspots (high (HH) or low (LL) fertility rates with similar neighbors) when the $z$-score was $>2$ and (ii) fertility cold spots (delineating a steep gradient of high-to-low (HL) or low-to-high (LH) fertility rates among neighbors) when the $z$-score was $<-2$.

To verify the suburban fertility hypothesis, the correlation between local fertility and the distance from downtown Athens was investigated through a U-shaped, second-order polynomial model, assuming higher fertility at intermediate distances from the inner city (suburban locations) and lower fertility at both lower (urban locations) and higher (rural locations) distances from the inner city. Based on the equation $Y=a x^{2}+b x+c$, where $\mathrm{Y}$ is the gross fertility rate, $x$ is the distance from downtown Athens, and $\mathrm{a}, \mathrm{b}$, and $\mathrm{c}$ are the polynomial (regression) coefficients, this model assumes Athens as a mono-centric region, in line with earlier evidence [102]. For each decade, the model's goodness-of-fit was estimated through the adjusted $\mathrm{R}^{2}$, testing against the null hypothesis of a non-significant model at $p<0.01$ with a Fisher-Snedecor F coefficient [117]. Finally, a Spearman nonparametric rank correlation test was run pair-wise between the decadal fertility rate and each contextual variable (Section 2.2) separately, for 1999-2008 and 2009-2018. This analysis allows the profiling of socioeconomic contexts associated with high, intermediate, and low fertility in Athens. Significant (positive or negative) correlations were tested at $p<0.05$, applying a Bonferroni's correction for multiple comparisons. 


\section{Results}

3.1. A Descriptive Analysis of Local Fertility Rates in Athens, 1991-2018

Figure 2a illustrates trends over time in fertility rates characteristic of seven regional units in the Athens metropolitan region. Fertility rates showed a similar trend during the whole study period, except for in Central Athens, which displayed a completely different pattern in the last few years. Generally speaking, fertility rates were maintained as low and stable during the 1990s, increasing during the 2000s, and reaching a relative peak in 2008 or 2009. A rapid decline was observed in the 2010s, except for in Central Athens, where a more intense fertility recovery since 2014 followed a moderate decline at the beginning of the decade. Fertility divides among the regional units were also evident; the lowest fertility was observed in Central Athens, ranging from 1.2 to 1.3 children per woman during the economic expansion and recession, respectively. The highest fertility rate (1.7-2.1 children per woman) was observed in Western Attica. Figure $2 b$ reports a selection of indicators summarizing the spatial dynamics of fertility in the study area. Taken together, these results confirm a moderate fertility recovery at the regional scale in correspondence with the economic expansion of the 2000s, and a slight decline afterward. Fertility divides between urban and peri-urban districts increased with expansion and decreased with recession. However, the spatial variability of fertility rates across regional units was rather high throughout the study period.

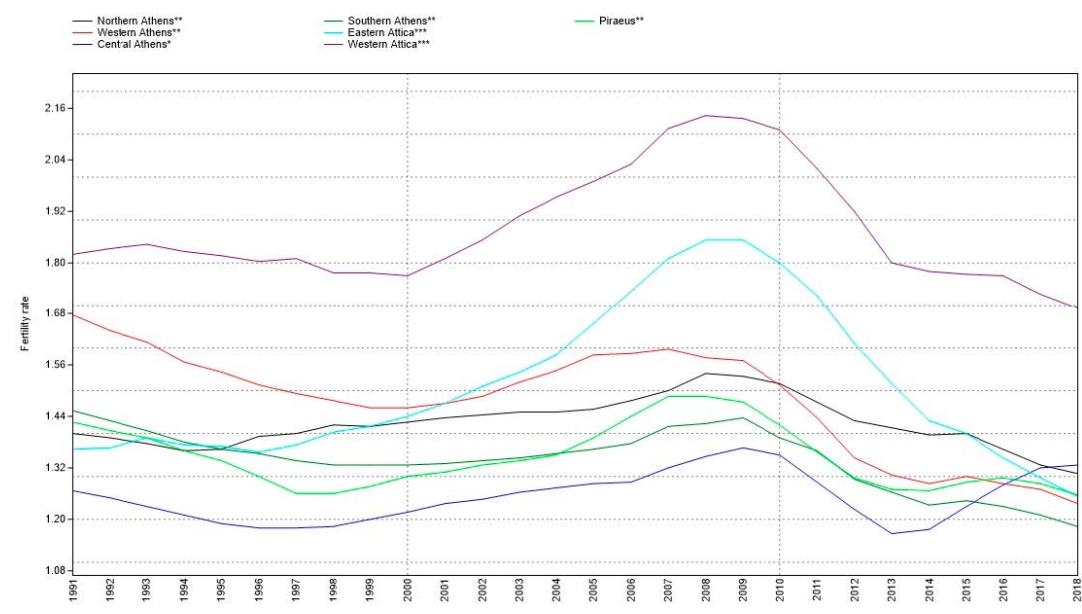

(a)

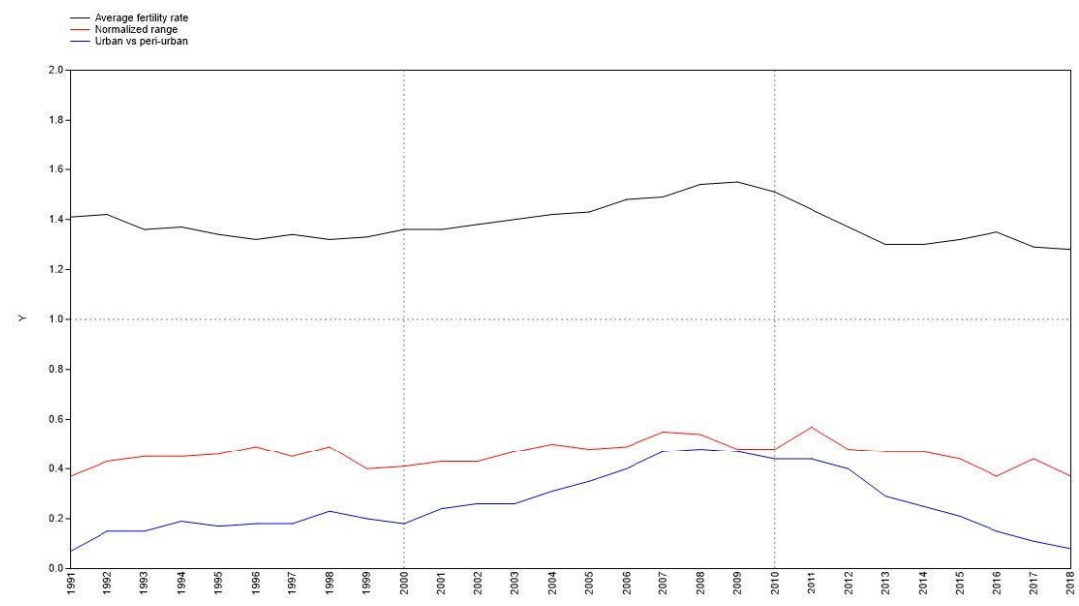

(b)

Figure 2. (a) Fertility rates (children per woman) over time (1991-2018) by regional unit; (b) selected

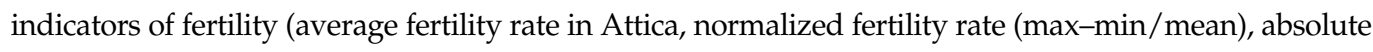
difference between two fertility rates observed in the Greater Athens area and the rest of Attica, respectively); ${ }^{*}$ inner city; ${ }^{* *}$ surrounding districts; ${ }^{* * *}$ peri-urban area. 
By separating the investigated period into three time intervals, Table 1 reports the aggregated gross fertility rates by regional unit in Attica. The most evident change in fertility rates was observed in locations outside the Greater Athens area, especially in Western Attica and, less intensively, in Eastern Attica. Central Athens was the district with the most stable (and low) fertility rate in the study area. The highest and lowest fertility rates were observed in the 2000s and the 1990s, respectively.

Table 1. Spatial distribution of gross fertility rate (children per woman) by regional unit in Attica (* inner city; ${ }^{* *}$ surrounding districts; ${ }^{* * *}$ peri-urban area).

\begin{tabular}{lccc}
\hline \multirow{2}{*}{ District } & \multicolumn{3}{c}{ Gross Fertility Rate } \\
\cline { 2 - 4 } & $\mathbf{1 9 9 1 - 2 0 0 0}$ & $\mathbf{2 0 0 0 - 2 0 0 8}$ & $\mathbf{2 0 0 9 - 2 0 1 8}$ \\
\hline Central Athens $^{*}$ & 1.21 & 1.28 & 1.27 \\
Piraeus $^{* *}$ & 1.33 & 1.38 & 1.32 \\
Northern Athens $^{* *}$ & 1.39 & 1.46 & 1.42 \\
Western Athens $^{* *}$ & 1.55 & 1.54 & 1.35 \\
Southern Athens $^{* *}$ & 1.37 & 1.37 & 1.29 \\
Eastern Attica & $* *$ & 1.63 & 1.52 \\
Western Attica & 1.38 & 1.97 & 1.87 \\
Attica, Grand Total & 1.81 & 1.43 & 1.37 \\
\hline
\end{tabular}

\subsection{Spatial Analysis, $1999-2018$}

Comparing the economic expansion (1999-2008) and recession (2009-2018), significantly higher fertility rates were recorded in peri-urban municipalities West of Athens (Thriasio) during the expansion. Spatial divides were more evident during the recession, when the highest fertility rates were observed both in Thriasio and Messoghia, the most populated peri-urban districts in Attica (Figure 3).
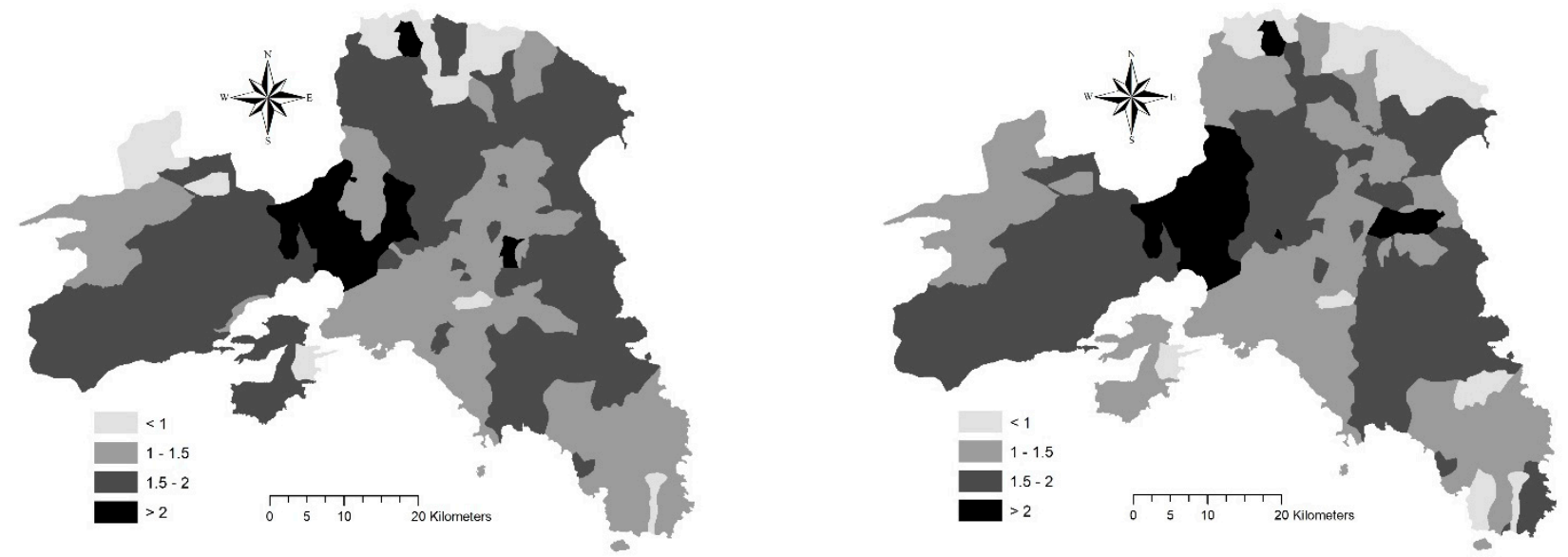

Figure 3. The spatial distribution of local fertility rates (children per woman, decadal average) at the municipal scale $(n=$ 115 domains) over two time intervals (1999-2008: left; 2009-2018: right).

The spatial distribution of gross fertility rates was quasi-normal in both decades (Figure 4), being more concentrated around the average value of 1.5 children per woman during the recession.

Analysis of global and local Moran's autocorrelation coefficients revealed substantial heterogeneity in the spatial distribution of gross fertility rates in Athens (Figure 5). Global coefficients were statistically insignificant for both expansion and recession (Table 2). Weak signals of spatial autocorrelation were observed with crisis. More specifically, a local gradient from high to low fertility rates was observed in both decades in the Oropos district (a rural area north of Athens with moderate urban expansion). A fertility cluster (high values) was observed in the Thriasio district (West of Athens) during the recession. 

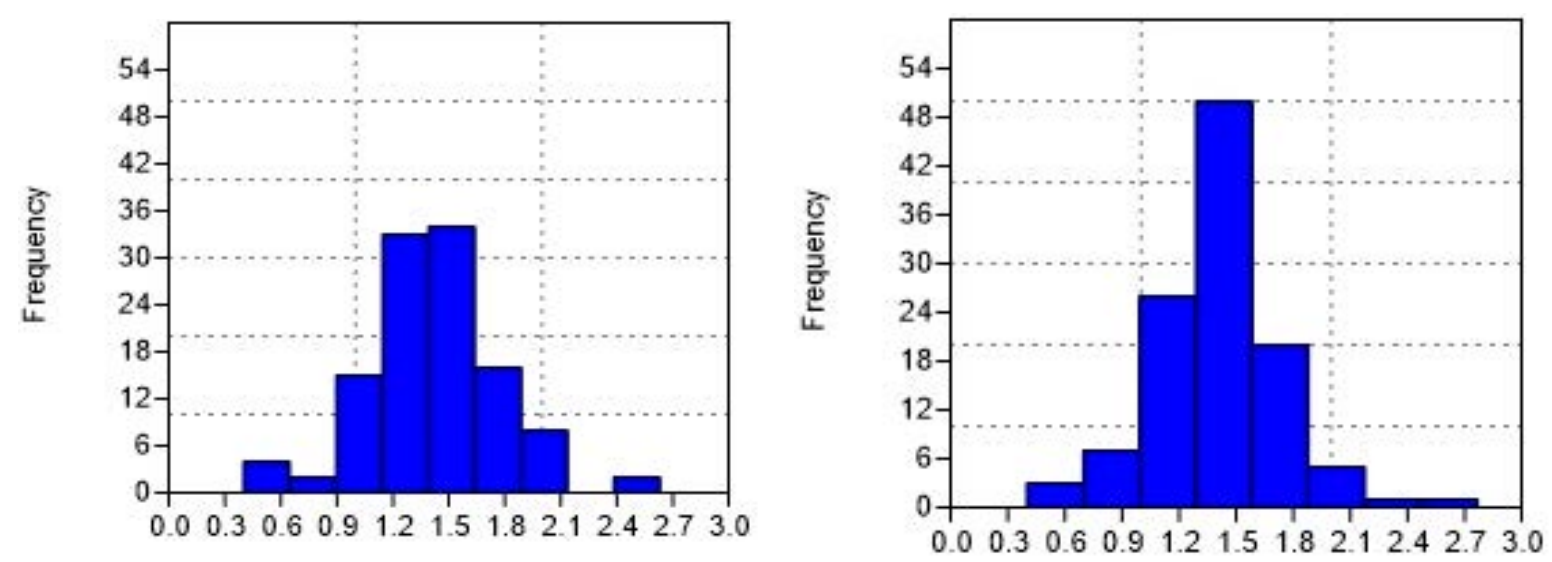

Figure 4. Absolute number of municipalities $(n=115)$ by fertility level (children per woman) in the study area (left: 1999-2008; right: 2009-2018).
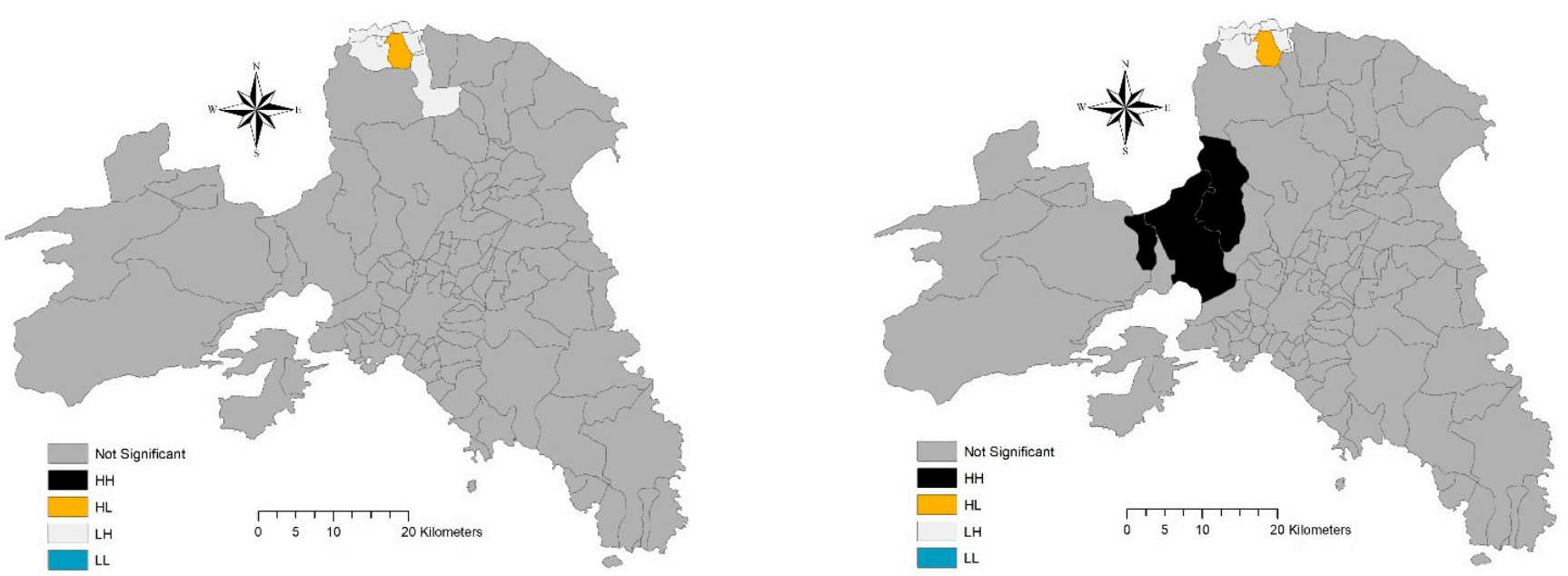

Figure 5. Local Moran's spatial autocorrelation coefficients of fertility rates (children per woman) over the study area (left: 1999-2008; right: 2009-2018).

Table 2. Global Moran's spatial autocorrelation coefficients of fertility rates (children per woman) in the study area by bandwidth $(\mathrm{km})$.

\begin{tabular}{ccc}
\hline \multirow{2}{*}{ Bandwidth (km) } & \multicolumn{2}{c}{ Coefficient $(p$-Level) } \\
\cline { 2 - 3 } & $\mathbf{1 9 9 9 - 2 0 0 8}$ & $\mathbf{2 0 0 9 - 2 0 1 8}$ \\
\hline 5 & $-1.46(0.14)$ & $-1.34(0.18)$ \\
10 & $-0.53(0.59)$ & $-0.22(0.83)$ \\
20 & $-0.62(0.53)$ & $-0.03(0.97)$ \\
40 & $-0.72(0.47)$ & $-0.32(0.75)$ \\
\hline
\end{tabular}

\subsection{Gross Fertility Rates and Socioeconomic Local Contexts}

Assuming Athens as a mono-centric model, the relationship between local fertility rates and distance from the inner city was explored, testing an inverse, U-shape polynomial form that indicated higher fertility rates at intermediate distances from downtown Athens (suburban locations) compared with locations at lower (urban) or higher (rural) distances. Higher suburban fertility was tested separately for economic expansion and recession (Figure 6). Empirical results confirm the validity of the suburban fertility hypothesis, although the coefficient of determination $\left(R^{2}\right)$ was relatively low in both decades, being slightly higher with recession (1999-2008: $\mathrm{R}^{2}=0.138, \mathrm{~F}=8.71, p=0.0003 ; 2009-2018$ : $\mathrm{R}^{2}=0.145 ; \mathrm{F}=9.40 ; p=0.0001$ ). In both cases, the highest fertility level (on average, 2.1 
and 2.0 children per woman in 1999-2008 and 2009-2018, respectively) was recorded at a distance from central Athens, encompassing $15 \mathrm{~km}$ and $25 \mathrm{~km}$, which includes most of the suburban locations in Attica (e.g., municipalities in the north-eastern and north-western Athens fringe, the Thriasio plain, and Western Messoghia districts).
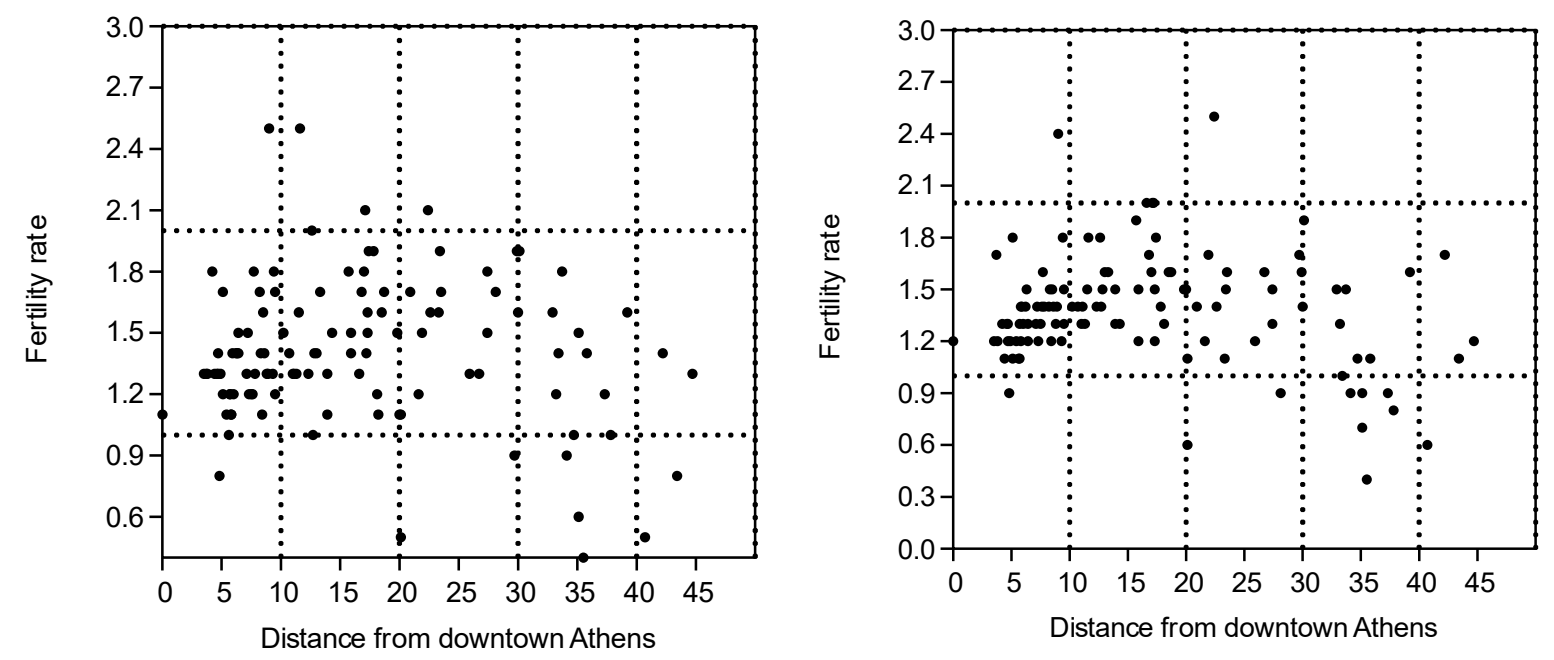

Figure 6. The relationship between local fertility rate (children per woman) and distance from downtown Athens (km) during 1999-2008 (left) and 2009-2018 (right) at the municipal scale ( $n=115$ domains) in the study area.

The relationship between gross fertility rates and socioeconomic predictors was evaluated, considering the preliminary findings of a Spearman analysis that identified significant (linear and non-linear) pair-wise correlations between variables (Table 3). With economic expansion, local fertility increased with climate quality index, per-capita built-up area, the share of one-dwelling buildings and industrial buildings in the total building stock, the extent of transport networks, and land-use with no current use, mining, and construction activities, as well as income and population growth. Conversely, fertility rates decreased with the spatial concentration of services and population aging. These findings highlight a characteristic spatial regime of fertility that reached the highest value in peri-urban, industrial areas (e.g., the Thriasio district) and the lowest value in compact, high-density urban areas. With recession, local fertility increased with the percent share of the discontinuous urban fabric in the total landscape, transport networks, land with no current use, income, and population growth, and decreased with aging. These findings evidence a more complex spatial regime, resulting in higher fertility typical of residential (non-industrial) suburban districts (e.g., Messoghia).

Population growth, income growth, land without current use, transport infrastructures, and aging were significant predictors of local fertility in both decades, corroborating earlier evidence in favor of the suburban fertility hypothesis in Athens. Accelerated population dynamics and strong resistance to economic shocks (income growth during crisis) characterized suburban locations with systematically higher fertility rates in both of the time intervals (i.e., irrespective of economic downturns). Economic downturns, however, seem to have had a side impact on suburban fertility, contributing to the acceleration of fertility dynamics in industrial areas during expansion and in residential places (with the working population mostly employed in services) during recession, respectively. These results suggest how industrial development, a pillar of Athens' growth in past decades, has had an indirect, positive impact on fertility dynamics, especially between the 1950s and the 1990s. Conversely, non-industrial, residential districts with higher (average) per-capita income were more resistant to crisis, displaying a less intense (negative) impact on fertility dynamics. 
Table 3. Results of a Spearman non-parametric correlation analysis between local fertility rates (children per woman, decadal average) and selected (contextual) predictors by time interval ("difference" means the absolute difference in local fertility rates between 2009-2018 and 1999-2008); significant pair-wise Spearman coefficients at $p<0.05$ were reported here, after Bonferroni's correction for multiple comparisons, $n=115$ ).

\begin{tabular}{|c|c|c|c|}
\hline Indicator & 1999-2008 & 2009-2018 & Difference \\
\hline Climate quality index & 0.32 & & \\
\hline Protected areas (dummy) & & & 0.24 \\
\hline Municipal master plan approved (dummy) & & & -0.27 \\
\hline Per-capita built-up area & 0.31 & & \\
\hline One-dwelling buildings in total building stock & 0.25 & & \\
\hline Industrial buildings in total building stock & 0.22 & & \\
\hline Discontinuous Medium Density Urban Fabric (30-50\%) & & 0.23 & \\
\hline Fast transit roads and associated land & 0.3 & 0.41 & \\
\hline Land without current use & 0.3 & 0.26 & \\
\hline Mining activities in total activities & 0.25 & & \\
\hline Energy activities in total activities & & & -0.22 \\
\hline Construction activities in total activities & 0.31 & & -0.26 \\
\hline Industrial activities at large & 0.3 & & -0.3 \\
\hline Services at large & -0.23 & & 0.26 \\
\hline Income growth rate during recession, 2008-2012 & 0.29 & 0.22 & \\
\hline Population growth rate & 0.26 & 0.4 & -0.23 \\
\hline Elderly index & -0.37 & -0.44 & \\
\hline
\end{tabular}

\section{Discussion}

Population dynamics were recognized to influence the attractiveness and economic performances of metropolitan regions worldwide [59,65,82-84]. Empirical studies on the relationship between economic conditions and demographic processes have recurrently shown that fertility has a pro-cyclical relationship with economic growth [107,108,118-121]. In Southern Europe, several regions have experienced significant demographic changes, with a transition from rigid family life courses toward a new regime of delayed marriage, increasing cohabitation, postponement of childbearing, and divorce or separation [8]. In such a context, the recession led to a profound deterioration of the labor market, with an unprecedented loss of jobs and acute effects on the economic situation, the conditions of life of families, and demographic behaviors [99]. The impact of the great recession on fertility was deeply investigated in Greece [98]. Total fertility rates in the 2000s increased as a result of the recuperation of births that were postponed during the 1990s [21]. The recent fall of birth rates was explained by the decline of fertility in younger women (less than 30 years old) [33], being indicative of a more generalized decrease of the complete fertility of women born after 1980 [112]. Despite such clear findings, it cannot be demised how earlier studies addressing both the counter- and pro-cyclical nature of fertility dynamics over economic downturns in Mediterranean Europe have been less conclusive [122,123].

The present study refines this country-level interpretative framework with a specific investigation of the Athens metropolitan region, integrating the analysis of impacts that economic downturns have on fertility, with the empirical testing of the suburban fertility hypothesis. In this perspective, investigating spatial similarities in local fertility rates over distinctive economic phases sheds light on the inherent socioeconomic transformation of metropolitan regions. Our study demonstrates that suburban fertility was persistently higher than urban and rural fertility in Athens during both expansion and recession, although with some differences observed in the socioeconomic local context during the two phases. While intense demographic change (population aging and high immigration rates) has accelerated the sequential waves of urbanization and suburbanization during economic expansion, the recession has significantly affected population dynamics, enlarging social disparities in Athens [101]. These results are in line with earlier evidence collected at a broader scale in Europe and outline how multifaceted migration trends, new house- 
hold structures, and population aging have influenced local fertility patterns [1,2,15,124]. Clarifying how urban cycles and economic downturns interact with socio-demographic dynamics to shape city competitiveness, attractiveness, and sustainability allows the identification of the intrinsic mechanisms at the base of local development and metropolitan expansion $[41,69,125]$.

While economic downturns seem to have impacted suburban birth rates more than urban (and rural) birth rates, this impact was relatively mild at the local level, in turn determining an increased demographic heterogeneity in both urban, suburban, and rural municipalities [13]. All these findings are in line with the assumptions of the suburban fertility hypothesis [93]. Although recent economic expansions reflected a (more or less) generalized fertility recovery $[8,33]$, higher suburban fertility was assumed to be dependent on specific forces (e.g., class segregation or social diversification, income disparities, asymmetries in the job market, migrations, changing lifestyles and beliefs, and increasing volatility in housing demand) interacting over longer time intervals [89,94]. Contrasting with earlier evidence across Europe [24,25], our results suggest that the recession has brought only a moderate decrease in fertility rates, despite an intense-although temporary-increase in unemployment rates $[99,100,105,107,112]$. These dynamics may determine delayed impacts on fertility rates that could be more clearly observed in the next few years, when the recession will display long-term societal impacts in Athens. However, the (recession-driven) moderate fertility decline was clearly associated with more polarized socio-spatial structures in Athens [102].

During economic expansion in Athens, birth rates increased heterogeneously over spaces, rising more rapidly in peri-urban (industrial) districts characterized by intermediate to low per-capita incomes and young populations. With the recession, fertility decline was more intense in such districts (where the population is likely more exposed to job instability, especially in the secondary sector), maintaining instead relatively high values in residential districts, with the population less exposed to unemployment or salary cuts [103]. Although in a context still in line with predictions of the suburban fertility hypothesis, differential fertility rates in industrial and residential peri-urban municipalities highlight the enlarging social polarization in affluent and disadvantaged neighborhoods [94]. These results definitely confirm that fertility trends in the study area reflect different sensitivities to expansion and crisis, going beyond the effects of the sole unemployment rate [108], and responding instead to a more subtle socioeconomic gradient based on spatial differences in income and wealth, class/ethnic segregation, and concentration of businesses [89]. Suburban economic functions and social traits typical of peri-urban locations are regarded as significant factors shaping fertility dynamics in both of the investigated decades. More specifically, these dimensions have fueled substantial divides in the birth rates between compact urban and rural areas, outlining the role of individual preferences and contextual factors at the base of the superior fertility of families living in suburban residences [126].

Based on these premises, three issues should be addressed in more detail in future studies, to try to reconnect the results obtained in our work at two spatial scales (regional units and municipalities). First, the inherent stability of district fertility rates over three sub-periods (declining slightly during 1991-2000, increasing until the crisis of 2008, and then decreasing from 2009 onward) should be better linked with a more heterogeneous (and likely, less predictable) pattern at the municipal scale, as the mixed results of the correlation analysis (Section 3.3) may indicate. For instance, local fertility in some districts, such as Western and Southern Athens, was less coherent with the general trend observed in other Greater Athens districts. This pattern is poorly explained with the different socioeconomic composition of neighborhoods (more affluent in Southern Athens and relatively more disadvantaged in Western Athens) and requires a deeper analysis of the intimate sources of local heterogeneity in fertility behaviors at both local and metropolitan levels [127]. At the same time, a refined investigation of social forces and economic mechanisms that underlie the differential fertility of peri-urban industrial areas and residential non-industrial suburban districts is needed in a changing metropolitan context, such as Athens. A specific analysis 
of the social composition of both areas-focusing also on the immigrant population-seems to be appropriate in this regard [128]. Such forces could be better understood when explaining the low fertility rates typical of rural areas during both expansion and recession [129]. A weak fertility response to economic downturns in low-fertility districts can be associated with "structural" factors, led by persistent unemployment, rural poverty, aging, and a progressive depopulation, indirectly reducing the childbearing propensity of the remaining young families [130]. A specific investigation based on integrated micro-macro data and field surveys may represent a novel contribution in this direction.

Second, the time interval under investigation in this study (1991-2018), and especially the 1990s and the 2000s, coincided with a significant influx of foreign, non-European immigrants to Greece. It was rather well-documented how fertility among non-European immigrants tends to be higher than that in the local native populations in the host countries [126-128]. The differential role of non-Western immigrants in fertility recovery before 2008 and the consequent reduction in the following years should be more clearly addressed using micro-data from administrative registers and population censuses [129]. Unfortunately, statistical information derived from population registers in Greece is rather partial and does not allow a specific investigation of this issue at a very detailed spatial scale, in contrast with other Mediterranean contexts [130]. These data could also allow the testing of different assumptions, hypothesizing that in areas with a high concentration of immigrants, the fertility of the local indigenous individuals could be lower, due to, for example, congestion diseconomies [131].

Third, a specific focus on education issues, for example., the so-called "educational white flight", could be an additional suggestion for further studies. This process implies a diverging pattern that distinguishes consolidated urban areas (where the native population usually prefers to send their children to expensive private schools) from more segregated suburban areas, where the student population in public schools is almost entirely native, and where people show much lower interest in private education [132-134]. As private education is more expensive, the private school choice may coincide with a lower fertility choice. This situation, typical of urban and suburban contexts in the United States, is likely more heterogeneous in major European cities, and especially in Mediterranean agglomerations, where an evident social mix was observed both in urban areas and in suburbs [135-137]. However, some preliminary evidence has been reported in recent studies dealing with Athens, depicting a very fragmented (and less predictable) social context characteristic of Southern European cities.

By shedding light on the inherent spatial divides in fertility levels between urban, suburban, and rural contexts, the empirical results of our study finally stimulate some reflections on the intrinsic linkage between regional demographic dynamics and metropolitan sustainability. Assuming a balanced interplay between social, economic, and environmental components at the base of sustainable development of urban systems, the demographic component is clearly predominant in the social dimension, contributing significantly to the evolution of urban systems [109-113], producing stimuli and impulses with impacts at various spatial scales and with consequences both in the economic and environmental fields. In this sense, fertility levels are a crucial element in understanding the demographic dynamics at multiple planning and intervention scales [111]. In the urban context, earlier studies have demonstrated how fertility dynamics, together with migration flows, have been a basic engine of urbanization, suburbanization, and re-urbanization [138]. With the decline of birth rates, this process has, in part, lost its centrality in urban cycles. However, at least in some countries most affected by the economic crisis, the recent decline in international migratory flows that were progressively oriented towards more attractive destinations with greater job opportunities, candidates' fertility as a demographic dimension assured social stability and more equitable local communities, for example, acting against urban shrinkage in some economically disadvantaged contexts [115,139-141].

More generally, an overview that integrates vital statistics and migration statistics indicates how, in a context of low immigration, a positive natural balance (more births than 
deaths) guarantees population stabilization or moderate/slow growth, fully compatible with sustainable development at the metropolitan scale. From an economic point of view, a slightly growing urban population guarantees the maintenance of adequate levels of attractiveness and competitiveness that make it possible to support industrial activities and advanced services. From the environmental point of view, a stable or slightly growing anthropogenic pressure also appears compatible with the achievement of objectives of land use containment, maintaining a satisfactory ecological standard that is difficult to achieve in high-growth contexts or in conditions of intense shrinking. The governance of local demographic dynamics in a perspective of urban resistance to external shocks is therefore indispensable, not only from a socio-political point of view but, above all, for its ecological and economic implications. Adequate regulation of demographic dynamics on an urban scale, with adequate policies to support fertility, allows regions to overcome the multiple impacts of the reduction of migratory flows (with the intrinsic decline of total fertility rates, since fertility levels are generally higher in foreign immigrants' communities than in the native population). Reducing social disparities on a metropolitan scale, governing processes of gentrification and social filtering, and containing class and ethnic segregation may also contribute to this target. In this way, through the demographic leverage, it is possible to act synergistically on the three dimensions of sustainability, shaping urban systems that are more resistant to exogenous shocks, more equitable from a social point of view, and more balanced from a spatial perspective.

\section{Conclusions}

The spatial analysis of a gross indicator of local fertility, accounting for both territorial heterogeneity and socioeconomic change, sheds light on the intimate mechanisms that regulate local fertility in metropolitan regions [126], and delineates new opportunities for (and constraints to) regional development policies. In a low-fertility context, policies promoting spatially balanced and socially cohesive development should consider specific demographic measures that support families and counteract the negative impact of economic downturns on fertility $[115,142,143]$. Under the assumption that urban, suburban, and rural districts display distinctive fertility patterns and trends, profiling the socioeconomic characteristics of such contexts forms the appropriate knowledge base to policies that directly (or indirectly) contribute to urban sustainability and metropolitan resilience. While being increasingly associated with lifestyle changes [144-146], future studies should clarify the role of fertility decline in suburban locations as an indicator of the progressive decline of some typical forms of urban expansion, including sprawl. Fertility patterns and trends may reflect-sometimes better than other indicators-social disparities in metropolitan regions, informing dedicated strategies toward more cohesive cities.

Author Contributions: Conceptualization, L.S. and R.S.; methodology, A.S. and G.E.; software, G.E.; validation, A.S.; formal analysis, L.S., A.G.-M. and A.S.; investigation, R.H.-C.-Z. and R.S.; resources, G.E. and R.H.-C.-Z.; data curation, G.E. and R.H.-C.-Z.; writing-original draft preparation, L.S., and A.G.-M.; writing-review and editing, R.S., and R.H.-C.-Z.; visualization, G.E.; supervision, A.S.; project administration, A.S.; funding acquisition, G.E. All authors have read and agreed to the published version of the manuscript.

Funding: This research received no external funding.

Conflicts of Interest: The authors declare no conflict of interest.

\section{References}

1. Adserà, A. Changing fertility rates in developed countries. The impact of labor market institutions. J. Popul. Econ. 2004, 17, 17-43. [CrossRef]

2. Bayona-Carrasco, J.; Gil-Alonso, F. Suburbanisation and international immigration: The case of the Barcelona Metropolitan Region (1998-2009). Tijdschr. Voor Econ. En Soc. Geogr. 2012, 103, 312-329. [CrossRef]

3. Bocquier, P.; Costa, R. Which transition comes first? Urban and demographic transitions in Belgium and Sweden. Demogr. Res. 2015, 33, 1297-1332. [CrossRef] 
4. Buckley, C. Rural/urban differentials in demographic processes: The Central Asian states. Popul. Res. Policy Rev. 1998, 17, 71-89. [CrossRef]

5. Caldwell, J.C. Demographic Transition Theory; Springer: Berlin, Germany, 2006.

6. Chelli, F.M.; Ciommi, M.; Emili, A.; Gigliarano, C.; Taralli, S. Assessing the Equitable and Sustainable Well-Being of the Italian Provinces. Int. J. Uncertain. Fuzziness Knowl. Based Syst. 2016, 24, 39-62. [CrossRef]

7. Evans, A.; Gray, E. Modelling Variation in Fertility Rates Using Geographically Weighted Regression. Spat. Demogr. 2018, 6, 121-140. [CrossRef]

8. Gavalas, V.S.; Rontos, K.; Salvati, L. Who becomes an unwed mother in Greece? Socio-demographic and geographical aspects of an emerging phenomenon. Popul. Space Place 2014, 20, 250-263. [CrossRef]

9. Goldstein, J.R.; Klüsener, S. Spatial analysis of the causes of the fertility decline in Prussia. Popul. Dev. Rev. 2014, 40, 497-525. [CrossRef]

10. Guilmoto, C.Z.; Rajan, S.I. Spatial patterns of fertility transition in Indian districts. Popul. Dev. Rev. 2001, 27, 713-738. [CrossRef]

11. Işik, O.; Pinarcioglu, M.M. Geographies of a silent transition: A geographically weighted regression approach to regional fertility differences in Turkey. Eur. J. Popul. 2006, 22, 399-421. [CrossRef]

12. Kulu, H. Why do fertility levels vary between urban and rural areas? Reg. Stud. 2013, 47, 895-912. [CrossRef]

13. Kulu, H.; Boyle, P.J.; Anderson, G. High Suburban fertility: Evidence from Four Northern European Countries. Demogr. Res. 2009, 31, 915-944. [CrossRef]

14. Lauf, S.; Haase, D.; Seppelt, R.; Schwarz, N. Simulating demography and housing demand in an urban region under scenarios of growth and shrinkage. Environ. Plan. B Plan. Des. 2012, 39, 229-246. [CrossRef]

15. Lerch, M. Fertility decline during Albania's societal crisis and its subsequent consolidation. Eur. J. Popul. 2013, 29, 195-220. [CrossRef]

16. Lerch, M. Regional variations in the rural-urban fertility gradients in global South. PLoS ONE 2019, 14, 1-19. [CrossRef] [PubMed]

17. Lesthaeghe, R.; Lopez-Gay, A. Spatial continuities and discontinuities in two successive demographic transitions: Spain and Belgium, 1880-2010. Demogr. Res. 2013, 28, 77-136. [CrossRef]

18. Liu, L. Fertility trends in China's more developed urban districts: The case of four cities. Popul. Space Place 2005, 11, 411-424. [CrossRef]

19. Michielin, F. Lowest low fertility in an urban context: The role of migration in Turin, Italy. Popul. Space Place 2004, 10, 331-347. [CrossRef]

20. Potter, J.E.; Schmertmann, C.P.; Assunção, R.M.; Cavenaghi, S.M. Mapping the timing, pace, and scale of the fertility transition in Brazil. Popul. Dev. Rev. 2010, 36, 283-307. [CrossRef]

21. Rontos, K. Prospects for a new family formation and for its impact on fertility: Some research evidences from Greece. Stat. Rev. 2007, 3, 1-9.

22. Sabater, A.; Graham, E. International migration and fertility variation in Spain during the economic recession: A spatial Durbin approach. Appl. Spat. Anal. Policy 2019, 12, 515-546. [CrossRef]

23. Schneider, D. The Great Recession, fertility, and uncertainty: Evidence from the United States. J. Marriage Fam. 2015, 77, 1144-1156. [CrossRef]

24. Sobotka, T. Postponement of Childbearing and Low Fertility in Europe; Dutch University Press: Amsterdam, The Netherlands, 2004.

25. Sobotka, T.; Skirbekk, V.; Philipov, D. Economic recession and fertility in the developed world. Popul. Dev. Rev. 2011, 37, 267-306. [CrossRef] [PubMed]

26. Surkyn, J.; Lesthaeghe, R. Value orientations and the second demographic transition (SDT) in Northern, Western and Southern Europe: An update. Demogr. Res. 2004, 3, 45-86. [CrossRef]

27. Thygesen, L.C.; Knudsen, L.B.; Keiding, N. Modelling regional variation of first-time births in Denmark 1980-1994 by an age-period-cohort model. Demogr. Res. 2005, 13, 573-590. [CrossRef]

28. Van de Kaa, D.J. Europe's second demographic transition. Popul. Bull. 1987, 42, 1-59.

29. Vitali, A.; Billari, F.C. Changing determinants of low fertility and diffusion: A spatial analysis for Italy. Popul. Space Place 2017, 23, e1998. [CrossRef]

30. Vignoli, D.; Drefahl, S.; De Santis, G. Whose job instability affects the likelihood of becoming a parent in Italy? A tale of two partners. Demogr. Res. 2012, 26, 41-62. [CrossRef]

31. Walford, N.; Kurek, S. Outworking of the Second Demographic Transition: National Trends and Regional Patterns of Fertility Change in Poland, and England and Wales, 2002-2012. Popul. Space Place 2016, 22, 508-525. [CrossRef]

32. Van Bavel, J. The reversal of gender inequality in education, union formation and fertility in Europe. Vienna Yearb. Popul. Res. 2012, 10, 127-154. [CrossRef]

33. Rontos, K. Demographic trends, young people's attitudes towards marriage and socio-economic changes related to family formation in Greece and in selected European Countries: A comparative analysis based on official and survey research data. Int. J. Criminol. Sociol. Theory 2010, 3, 543-562.

34. Rodriguez-Rodriguez, V. The seven demographic Spains. Inter-municipal contrasts in age structure: Fertility and migration are the determining factors. Espace Popul. Soc. 2000, 18, 425-435.

35. Wachter, K.W. Spatial demography. Proc. Natl. Acad. Sci. USA 2005, 102, 15299-15300. [CrossRef]

36. Voss, P.R. Demography as a spatial social science. Popul. Res. Policy Rev. 2007, 26, 457-476. [CrossRef] 
37. Waldorf, B.; Franklin, R. Spatial dimensions of the Easterlin hypothesis: Fertility variations in Italy. J. Reg. Sci. 2002, 42, 549-578. [CrossRef]

38. Adsera, A. An Economic Analysis of the Gap between Desired and Actual Fertility: The Case of Spain. Rev. Econ. Househ. 2006, 4, 75-95. [CrossRef]

39. Arpino, B.; Patrício Tavares, L. Fertility and Values in Italy and Spain: A Look at Regional Differences within the European Context. Popul. Rev. 2013, 52, 62-86.

40. Billari, F.; Kohler, H.P. Patterns of low and lowest-low fertility in Europe. Popul. Stud. 2004, 58, 161-176. [CrossRef]

41. Cabré, A. Facts and Factors on Low Fertility in Southern Europe. The Case of Spain. J. Popul. Soc. Secur. (Popul.) 2003, S1, 309-321.

42. Bongaarts, J.; Watkins, S.C. Social Interactions and Contemporary Fertility Transitions. Popul. Dev. Rev. 1996, $22,639-682$. [CrossRef]

43. Caldwell, J.C.; Schindlmayr, T. Explanations of the fertility crisis in modern societies: A search for commonalities. Popul. Stud. 2003, 57, 241-263. [CrossRef] [PubMed]

44. Caltabiano, M. Has the fertility decline come to an end in the different regions of Italy? New insights from a cohort approach. Population 2008, 63, 157-172. [CrossRef]

45. Carlucci, M.; Chelli, F.M.; Salvati, L. Toward a new cycle: Short-term population dynamics, gentrification, and re-urbanization of Milan (Italy). Sustainability 2018, 10, 3014. [CrossRef]

46. Chelli, F.; Gigliarano, C.; Mattioli, E. The impact of inflation on heterogeneous groups of households: An application to Italy. Econ. Bull. 2009, 29, 1276-1295.

47. Cherlin, A.; Cumberworth, E.; Morgan, S.P.; Wimer, C. The effects of the Great Recession on family structure and fertility. Ann. Am. Acad. Political Soc. Sci. 2013, 650, 214-223. [CrossRef]

48. Ciganda, D. Unstable work histories and fertility in France: An adaptation of sequence complexity measures to employment trajectories. Demogr. Res. 2015, 32, 843-876. [CrossRef]

49. Ciommi, M.; Chelli, F.M.; Carlucci, M.; Salvati, L. Urban growth and demographic dynamics in southern Europe: Toward a new statistical approach to regional science. Sustainability 2018, 10, 2765. [CrossRef]

50. Coppola, L.; Di Cesare, M. How fertility and union stability interact in shaping new family patterns in Italy and Spain. Demogr. Res. 2008, 18, 117-144. [CrossRef]

51. Del Bono, E.; Weber, A.; Winter-Ebmer, R. Fertility and economic instability: The role of unemployment and job displacement. J. Popul. Econ. 2015, 28, 46-479.

52. Frejka, T.; Sobotka, T. Fertility in Europe: Diverse, delayed and below replacement. Demogr. Res. 2008, 19, 15-46. [CrossRef]

53. Georgiadis, K. Fertile debates: A comparative account of low fertility in the British and Greek national press. Eur. J. Popul. 2011, 27, 243-262. [CrossRef]

54. Goldstein, J.; Kreyenfeld, M.; Jasilioniene, A.; Örsal, D.D.K. Fertility reactions to the "Great Recession” in Europe: Recent evidence from order-specific data. Demogr. Res. 2013, 29, 85-104. [CrossRef]

55. Hofmann, B.; Hohmeyer, K. Perceived economic uncertainty and fertility: Evidence from a labor market reform. J. Marriage Fam. 2013, 75, 503-521. [CrossRef]

56. Kreyenfeld, M. Uncertainties in female employment careers and the postponement of parenthood in Germany. Eur. Sociol. Rev. 2010, 26, 351-366. [CrossRef]

57. Lee, K.O.; Painter, G. What happens to household formation in a recession? J. Urban Econ. 2013, 76, 93-109. [CrossRef]

58. Modena, F.; Rondinelli, C.; Sabatini, F. Economic insecurity and fertility intentions: The case of Italy. Rev. Income Wealth 2014, 60, S233-S255. [CrossRef]

59. Schneider, F.; Kallis, G.; Martinez-Alier, J. Crisis or opportunity? Economic degrowth for social equity and ecological sustainability. J. Clean. Prod. 2010, 18, 511-518. [CrossRef]

60. Lesthaeghe, R.J.; Neidert, L. The second demographic transition in the United States: Exception or textbook example? Popul. Dev. Rev. 2006, 32, 669-698. [CrossRef]

61. Martín García, T. The impact of occupational sex-composition on women's fertility in Spain. Eur. Soc. 2010, 12, 113-133. [CrossRef]

62. Morgan, S.P. Is low fertility a twenty-first-century demographic crisis? Demography 2003, 40, 589-603. [CrossRef]

63. Cazzola, A.; Pasquini, L.; Angeli, A. The relationship between unemployment and fertility in Italy: A time-series analysis. Demogr. Res. 2016, 34, 1-3. [CrossRef]

64. Caltabiano, M.; Castiglioni, M.; Rosina, A. Lowest-low fertility: Signs of a recovery in Italy? Demogr. Res. 2009, 21, 681-718. [CrossRef]

65. Carbonaro, C.; Leanza, M.; McCann, P.; Medda, F. Demographic decline, population aging, and modern financial approaches to urban policy. Int. Reg. Sci. Rev. 2018, 41, 210-232. [CrossRef]

66. Chelli, F.; Rosti, L. Age and gender differences in Italian workers' mobility. Int. J. Manpow. 2002, 23, 313-325. [CrossRef]

67. Hondroyiannis, G.; Papapetrou, E. Demographic transition and economic growth: Empirical evidence from Greece. J. Popul. Econ. 2002, 15, 221-242. [CrossRef]

68. Kirk, D. Demographic transition theory. Popul. Stud. 1996, 50, 361-387. [CrossRef]

69. Kabisch, N.; Haase, D. Diversifying European agglomerations: Evidence of urban population trends for the 21st century. Popul. Space Place 2011, 17, 236-253. [CrossRef] 
70. Kreyenfeld, M.; Andersson, G.; Pailhé, A. Economic uncertainty and family dynamics in Europe: Introduction. Demogr. Res. 2012, 27, 835-852. [CrossRef]

71. Martin-Garcia, T.; Castro-Martín, T. Do women working in the public sector have it easier to become mothers in Spain? Popul. Rev. 2013, 52, 149-171.

72. Bocquier, P.; Bree, S. A regional perspective on the economic determinants of urban transition in 19th-century France. Demogr. Res. 2018, 38, 1535-1576. [CrossRef]

73. Balbo, N.; Billari, F.C.; Mills, M. Fertility in advanced societies: A review of research. Eur. J. Popul. 2013, 29, 1-38. [CrossRef] [PubMed]

74. Buzar, S.; Ogden, P.E.; Hall, R. Households matter: The quiet demography of urban transformation. Prog. Hum. Geogr. 2005, 29, 413-436. [CrossRef]

75. Castro, M.C. Spatial demography: An opportunity to improve policy making at diverse decision levels. Popul. Res. Policy Rev. 2007, 26, 477-509. [CrossRef]

76. Chi, G.; Zhu, J. Spatial regression models for demographic analysis. Popul. Res. Policy Rev. 2008, 27, 17-42. [CrossRef]

77. Ciommi, M.; Gigliarano, C.; Emili, A.; Taralli, S.; Chelli, F.M. A new class of composite indicators for measuring well-being at the local level: An application to the Equitable and Sustainable Well-being (BES) of the Italian Provinces. Ecol. Indic. 2017, 76, 281-296. [CrossRef]

78. Cooke, L.P. Gender equity and fertility in Italy and Spain. J. Soc. Policy 2009, 38, 123-140. [CrossRef]

79. Goldstein, J.R.; Sobotka, T.; Jasilioniene, A. The end of lowest-low fertility? Popul. Dev. Rev. 2009, 35, 663-700.

80. Kohler, H.P.; Billari, F.C.; Ortega, J.A. The emergence of lowest-low fertility in Europe during the 1990s. Popul. Dev. Rev. 2002, 28, 641-680. [CrossRef]

81. Kaika, M. The economic crisis seen from the everyday: Europe's nouveau poor and the global affective implications of a 'local' debt crisis. City 2012, 16, 422-430. [CrossRef]

82. Hank, K. Regional social contexts and individual fertility decisions: A multilevel analysis of first and second births in western Germany. Eur. J. Popul. 2002, 18, 281-299. [CrossRef]

83. Haase, A.; Kabisch, S.; Steinführer, A.; Bouzarovski, S.; Hall, R.; Ogden, P. Spaces of reurbanisation: Exploring the demographic dimension of inner-city residential change in a European setting. Popul. Space Place 2010, 16, 443-463. [CrossRef]

84. Kroll, F.; Kabisch, N. The Relation of Diverging Urban Growth Processes and Demographic Change along an Urban-Rural Gradient, Population. Space Place 2012, 18, 260-276. [CrossRef]

85. Lerch, M. The role of migration in the urban transition: A demonstration from Albania. Demography 2014, 51, 1527-1550. [CrossRef] [PubMed]

86. Ogden, P.E.; Hall, R. Households, reurbanisation and the rise of living alone in the principal French cities 1975-1990. Urban Stud. 2000, 37, 367-390. [CrossRef]

87. Pison, G. Two children per woman in France in 2010: Is French fertility immune to economic crisis? Popul. Soc. 2011, 476, 1.

88. Pérez, J.M.G. The real estate and economic crisis: An opportunity for urban return and rehabilitation policies in Spain. Sustainability 2010, 2, 1571-1601. [CrossRef]

89. Panori, A.; Psycharis, Y.; Ballas, D. Spatial segregation and migration in the city of Athens: Investigating the evolution of urban socio-spatial immigrant structures. Popul. Space Place 2018, 25, e2209. [CrossRef]

90. Rees, P.; Bell, M.; Kupiszewski, M.; Kupiszewska, D.; Ueffing, P.; Bernard, A.; Edwards, E.C.; Stillwell, J. The impact of internal migration on population redistribution: An international comparison. Popul. Space Place 2017, 23, e2036. [CrossRef]

91. Stockdale, A. Contemporary and 'Messy' Rural In-migration Processes: Comparing Counterurban and Lateral Rural Migration. Popul. Space Place 2016, 22, 599-616. [CrossRef]

92. Kulu, H.; Boyle, P.J. High fertility in city suburbs: Compositional or contextual effects? Eur. J. Popul. 2009, 25, 157-174. [CrossRef]

93. Kulu, H.; Vikat, A. Fertility differences by housing type: The effect of housing conditions or of selective moves? Demogr. Res. 2007, 17, 775-802. [CrossRef]

94. Arapoglou, V.P.; Sayas, J. New facets of urban segregation in southern Europe-gender, migration and social class change in Athens. Eur. Urban Reg. Stud. 2009, 16, 345-362. [CrossRef]

95. Angel, S.; Parent, J.; Civco, D.L.; Blei, A.; Potere, D. The dimensions of global urban expansion: Estimates and projections for all countries, 2000-2050. Prog. Plan. 2011, 75, 53-107. [CrossRef]

96. Gil-Alonso, F.; Bayona-i-Carrasco, J.; Pujadas-i-Rúbies, I. From boom to crash: Spanish urban areas in a decade of change (2001-2011). Eur. Urban Reg. Stud. 2016, 23, 198-216. [CrossRef]

97. Lerch, M. Internal and international migration across the urban hierarchy in Albania. Popul. Res. Policy Rev. 2016, 35, 851-876. [CrossRef] [PubMed]

98. Chorianopoulos, I.; Tsilimigkas, G.; Koukoulas, S.; Balatsos, T. The shift to competitiveness and a new phase of sprawl in the Mediterranean city: Enterprises guiding growth in Messoghia-Athens. Cities 2014, 39, 133-143. [CrossRef]

99. Tragaki, A.; Bagavos, C. Fertility variations in the recession context: The case of Greece. Genus 2019, 75, 18. [CrossRef]

100. Tragaki, A.; Bagavos, C. Male fertility in Greece: Trends and differentials by educational level and employment status. Demogr. Res. 2014, 31, 137-160. [CrossRef]

101. Salvati, L. The dark side of the crisis: Disparities in per-capita income (2000-2012) and the urban-rural gradient in Greece. Tijdschrift voor Economische en Sociale Geografie 2016, 107, 628-641. [CrossRef] 
102. Salvati, L.; Ferrara, A.; Chelli, F. Long-term growth and metropolitan spatial structures: An analysis of factors influencing urban patch size under different economic cycles. Geogr. Tidsskr. Dan. J. Geogr. 2018, 118, 56-71. [CrossRef]

103. Rontos, K.; Grigoriadis, S.; Sateriano, A.; Syrmali, M.; Vavouras, I.; Salvati, L. Lost in Protest, Found in Segregation: Divided Cities in the Light of the 2015 'Oki' Referendum in Greece. City Cult. Soc. 2016, 7, 139-148. [CrossRef]

104. Ciommi, M.; Chelli, F.M.; Salvati, L. Integrating parametric and non-parametric multivariate analysis of urban growth and commuting patterns in a European metropolitan area. Qual. Quant. 2019, 53, 957-979. [CrossRef]

105. Gkartzios, M. 'Leaving Athens': Narratives of counterurbanisation in times of crisis. J. Rural Stud. 2013, 32, 158-167. [CrossRef]

106. Souliotis, N. Cultural economy, sovereign debt crisis and the importance of local contexts: The case of Athens. Cities 2013, 33, 61-68. [CrossRef]

107. Remoundou, K.; Gkartzios, M.; Garrod, G. Conceptualizing Mobility in Times of Crisis: Towards Crisis-Led Counterurbanization? Reg. Stud. 2016, 50, 1663-1674. [CrossRef]

108. Gkartzios, M.; Scott, K. A cultural panic in the province? Counterurban mobilities, creativity, and crisis in Greece. Popul. Space Place 2015, 21, 843-855. [CrossRef]

109. Dijkstra, L.; Garcilazo, E.; McCann, P. The effects of the global financial crisis on European regions and cities. J. Econ. Geogr. 2015, 15, 935-949. [CrossRef]

110. Muniz, J.O. Spatial dependence and heterogeneity in ten years of fertility decline in Brazil. Popul. Rev. 2009, 48, 32-65.

111. Toulemon, L. Fertility among immigrant women: New data a new approach. Popul. Soc. 2004, 400, 1-4.

112. Bagavos, C.; Verropoulou, G.; Tsimbos, C. Assessing the contribution of foreign women to period fertility in Greece, $2004-2012$. Population 2018, 73, 115-130.

113. Adsera, A. Marital fertility and religion in Spain, 1985 and 1999. Popul. Stud. 2006, 60, 205-221. [CrossRef] [PubMed]

114. Gigliarano, C.; Chelli, F.M. Measuring inter-temporal intragenerational mobility: An application to the Italian labour market. Qual. Quant. 2016, 50, 89-102. [CrossRef]

115. Kalwij, A. The impact of family policy expenditure on fertility in western Europe. Demography 2010, 47, 503-519. [CrossRef]

116. Rosti, L.; Chelli, F. Higher education in non-standard wage contracts. Educ. Train. 2012, 54, 142-151. [CrossRef]

117. Lamonica, G.R.; Chelli, F.M. The performance of non-survey techniques for constructing sub-territorial input-output tables. Pap. Reg. Sci. 2018, 97, 1169-1202. [CrossRef]

118. Garcia, M. The breakdown of the Spanish urban growth model: Social and territorial effects of the global crisis. Int. J. Urban Reg. Res. 2010, 34, 967-980. [CrossRef]

119. Billari, F.C.; Kohler, H.-P.; Andersson, G.; Lundström, H. Approaching the limit: Long-term trends in late and very late fertility. Popul. Dev. Rev. 2007, 33, 149-170. [CrossRef]

120. Oinonen, E. Starting the first family. Chang. Patterns Fam. Form. Demogr. Trends Finl. Spain. Eur. Soc. 2004, 6, 319-346. [CrossRef]

121. Palloni, A.; Tienda, M. Demographic responses to economic recessions in Latin America since 1900. Sociol. Inq. 1992, 62, 246-270. [CrossRef]

122. De Beer, J.; Deerenberg, I. An explanatory model for projecting regional fertility differences in the Netherlands. Popul. Res. Policy Rev. 2007, 26, 511-528. [CrossRef]

123. Wang, D.; Chi, G. Different Places, Different Stories: A Study of Spatial Heterogeneity of County-Level Fertility in China. Demogr. Res. 2017, 37, 493. [CrossRef] [PubMed]

124. Brodmann, S.; Esping-Andersen, G.; Güell, M. When Fertility is Bargained: Second Births in Denmark and Spain. Eur. Sociol. Rev. 2007, 23, 599-613. [CrossRef]

125. Rosti, L.; Chelli, F. Self-employment among Italian female graduates. Educ. Train. 2009, 51, 526-540. [CrossRef]

126. Strozza, S.; Benassi, F.; Ferrara, R.; Gallo, G. Recent demographic trends in the major Italian urban agglomerations: The role of foreigners. Spat. Demogr. 2016, 4, 39-70. [CrossRef]

127. Benassi, F.; Bonifazi, C.; Heins, F.; Lipizzi, F.; Strozza, S. Comparing residential segregation of migrant populations in selected European Urban and metropolitan areas. Spat. Demogr. 2020, 1-22. [CrossRef]

128. Benassi, F.; Iglesias-Pascual, R.; Salvati, L. Residential segregation and social diversification: Exploring spatial settlement patterns of foreign population in Southern European cities. Habitat Int. 2020, 101, 102200. [CrossRef]

129. Salvati, L.; Benassi, F. Rise (and Decline) of European Migrants in Greece: Exploring Spatial Determinants of Residential Mobility (1988-2017), with Special Focus on Older Ages. J. Int. Migr. Integr. 2020, 1-15. [CrossRef]

130. López-Gay, A.; Andújar-Llosa, A.; Salvati, L. Residential Mobility, Gentrification and Neighborhood Change in Spanish Cities: A Post-Crisis Perspective. Spat. Demogr. 2020, 1-28. [CrossRef]

131. Azarnert, L.V. Migration, Congestion and Growth. Macroecon. Dyn. 2019, 23, 3035-3064. [CrossRef]

132. Lankford, H.; Wyckoff, J. The effect of school choice and residential location on the racial segregation of students. In Advances in Applied Microeconomics; Gronberg, T.J., Jensen, D.W., Eds.; Emerald Group Publishing Limited: Bingley, UK, 2006; Volume 14, pp. 185-239.

133. Azarnert, L.V. Integrated Public Education, Fertility and Human Capital. Educ. Econ. 2014, 22, 166-180. [CrossRef]

134. Maloutas, T.; Ramos Lobato, I. Education and social reproduction: Educational mechanisms and residential segregation in Athens and Dortmund. Local Econ. 2015, 30, 800-817. [CrossRef]

135. Maloutas, T.; Spyrellis, S.N.; Capella, A. Residential segregation and educational performance. Case Athens. Urban Stud. 2019, 56, 3143-3161. [CrossRef] 
136. Maloutas, T. Middle class education strategies and residential segregation in Athens. J. Educ. Policy 2007, 22, 49-68. [CrossRef]

137. Maloutas, T.; Spyrellis, S.; Hadjiyanni, A.; Capella, A.; Valassi, D. Residential and school segregation as parameters of educational performance in Athens. Cybergeo Eur. J. Geogr. 2019, 917, 1-20. [CrossRef]

138. Zaidi, B.; Morgan, P. The second demographic transition theory: A Review and Appraisal. Annu. Rev. Sociol. 2017, 43, 473-492. [CrossRef]

139. Butler, D. The fertility riddle. Nature 2004, 432, 38-39. [CrossRef]

140. Bernardi, F. Public policies and low fertility: Rationales for public intervention and a diagnosis for the Spanish case. J. Eur. Soc. Policy 2005, 15, 123-138. [CrossRef]

141. Oueslati, W.; Alvanides, S.; Garrod, G. Determinants of urban sprawl in European cities. Urban Stud. 2015, 52, 1594-1614. [CrossRef]

142. Boyle, P. Population geography: Does geography matter in fertility research? Prog. Hum. Geogr. 2003, 27, 615-626. [CrossRef]

143. Pili, S.; Grigoriadis, E.; Carlucci, M.; Clemente, M.; Salvati, L. Towards sustainable growth? A multi-criteria assessment of (changing) urban forms. Ecol. Indic. 2017, 76, 71-80. [CrossRef]

144. Duvernoy, I.; Zambon, I.; Sateriano, A.; Salvati, L. Pictures from the other side of the fringe: Urban growth and peri-urban agriculture in a post-industrial city (Toulouse, France). J. Rural Stud. 2018, 57, 25-35. [CrossRef]

145. Cuadrado-Ciuraneta, S.; Durà-Guimerà, A.; Salvati, L. Not only tourism: Unravelling suburbanization, second-home expansion and "rural" sprawl in Catalonia, Spain. Urban Geogr. 2017, 38, 66-89. [CrossRef]

146. Salvati, L.; Zambon, I.; Chelli, F.M.; Serra, P. Do spatial patterns of urbanization and land consumption reflect different socioeconomic contexts in Europe? Sci. Total Environ. 2018, 625, 722-730. [CrossRef] [PubMed] 